This manuscript is contextually identical with the following published paper:

Mozsár A, Boros G, Sály P, Antal L, Nagy SA (2015) Relationship between Fulton’s condition factor and proximate body composition in three freshwater fish species. JOURNAL OF APPLIED ICHTHYOLOGY-ZEITSCHRIFT FÜR ANGEWANDTE ICHTHYOLOGIE 31:(2) pp. 315-320. DOI: 10.1111/jai.12658

The original published pdf available in this website:

http://onlinelibrary.wiley.com/doi/10.1111/jai.12658/abstract?userIsAuthenticated=f alse \&deniedAccessCustomisedMessage $=$

\title{
Relationship between Fulton's condition factor and proximate body composition in three freshwater fish species
}

Attila Mozsár ${ }^{1,2^{*}}$, Gergely Boros ${ }^{1}$, Péter Sály $^{1}$, László Antal $^{2}$, Sándor Alex Nagy ${ }^{2}$

1 MTA Centre for Ecological Research, Balaton Limnological Institute, Tihany, Hungary

${ }^{2}$ Department of Hydrobiology, University of Debrecen, Debrecen, Hungary

*Corresponding author: mozsar.attila@okologia.mta.hu

\section{Summary}

Morphometric-based condition indices are widely used to assess proximate body composition and collaterally, feeding and living conditions of fish. However, the exact relationship between condition indices and proximate body composition of fish 
and its relatedness to life history traits and seasonality have not been fully explored yet. Therefore, the aim of this study was to examine how the Fulton's condition factor (K-factor) is related to the chemical composition (i.e., lipid, protein, water and carbon content, and molar carbon: nitrogen ratio), length and gonadal development of fish, and how these relationships are influenced by gender and seasonality in three freshwater fish species: Amur sleeper (Perccottus glenii), pumpkinseed (Lepomis gibbosus) and rudd (Scardinius erythrophthalmus). We found that the strength and direction of association between the K-factor and proximate body composition can vary markedly among fish species. The K-factor correlated positively with gonadal development in pumpkinseed and Amur sleeper, while no such relationship existed in rudd. Condition factor can be a reliable measure of lipid content; however, the relationship was stronger in species with higher and more variable lipid contents. Moreover, we found striking and consistently negative linkage between the K-factor and water content of the fish body, which correspond with the findings of several other studies. In turn, we could not detect any relationship between the K-factor and protein content of fish. Gender seemed to exert negligible effect on the relationship between the K-factor and proximate body composition, while seasonal variance was obvious in most relationships. 


\section{Introduction}

A number of direct and indirect indices provide simplified methods to assess the nutritional status and relative health of fishes. The direct indices (e.g., gonadosomatic, hepatosomatic, visceral somatic index) may describe the life history traits, nutritional status and responses of fish to environmental effects (Brown and Murphy, 2004). The commonly used indirect indices (e.g., condition factor, relative weight), also known as morphometric indices, are based on external measures of lengthweight relationships and their applicability arise from the assumption that a heavier fish of a given length has greater energy reserves and consequently is in better condition (Bolger and Connolly, 1989). One of the most frequently used morphometric indices is the Fulton's condition factor (K-factor thereafter), expressed as the ratio of body mass and the cube of length (Nash et al., 2006). Several studies confirmed the strong positive relationship between the K-factor and total lipid content of fish (e.g., Herbinger and Friars, 1991; Chellappa et al., 1995) and assigned $\mathrm{K}$-factor as a simple proxy of energy reserves in fish body.

Lipid reserves are among the most important energy resources in fish bodies, playing an essential role in the health, growth, reproductive fitness and overwintering survival of individuals (Love, 1970; Hurst and Conover, 2003). In addition, the size of lipid storages affects the ability of fish to cope with different environmental stressors, such as parasites or extreme weather conditions (Fechhelm et al., 1995; Neff and Cargnelli, 2004). Thus, the reliable assessment of the lipid density in fish can be the keystone in various levels of ecological investigations. Besides the positive coupling between K-factor and lipid content of fish, Pangle and Sutton (2005) demonstrated that there is a strong linkage between K-factor, protein content and water content of fish. Other authors also reported the occurrence of the same 
trends between length-weight based morphometric indices and proximate composition of fish (Brown and Murphy, 1991; Sutton et al., 2000). In turn, some other studies reported no or very weak correlations between morphometric-based indices and lipid content of fish. For instance, Davidson and Marshall (2010) found that the K-factor cannot be used as an accurate measure of fat content in North Sea herring (Clupea harengus), while McPherson et al. (2011) studied the same species and reported weak relationship between K-factor and whole body fat content. Similar results were obtained in Atlantic salmons (Salmo salar) (Kardi et al., 1995) and muskellunges (Esox masquinongy) (Jonas et al., 1996). Finally, a preceding study on the intraspecific differences in the elemental composition of fish (Boros et al., 2012) revealed significantly negative correlation between total carbon content and K-factor of roach (Rutilus rutilus), a widespread cyprinid fish species in Europe. As lipids consist mainly of carbon (Fagan et al., 2011), we can deduce that the relationship between K-factor and lipid content was also negative in that study.

In the light of these conflicting results, the ultimate applicability of morphometric indices as reliable predictors of the proximate composition of fish is questionable and warrant more detailed examinations. The relationship between body composition and K-factor can be influenced by many factors; e.g., it can vary among populations (Kaufman et al., 2007) and seasons (Simpson et al., 1992), and it may also change with sexual maturity (McPherson et al., 2011). Because of the variability among the results of previous studies, we hypothesized that the relationship may have a speciesspecific aspect, besides the impacts of the factors mentioned above. To test this assumption, three freshwater fish species were sampled simultaneously from the same habitat. The aim of the study was to examine how the K-factor is related to the chemical composition (i.e., lipid, protein, water and carbon content, and molar 
carbon to nitrogen ratio), body length and gonadal development (i.e., gonado-somatic index) of different fish species, and to what extent these relationships are influenced by gender and seasonality.

\section{Materials and methods}

Fish were sampled in a eutrophic oxbow lake connected to River Tisza, situated in the north-eastern part of Hungary $\left(48^{\circ} 05^{\prime} \mathrm{N}, 21^{\circ} 27^{\prime} \mathrm{E}\right)$, during the spring (April), summer (July), and autumn (October) of 2012. The oxbow has a surface area of 0.9 $\mathrm{km}^{2}$ and a mean depth of $1.8 \mathrm{~m}$. The sampled fish species were the Amur sleeper (Perccottus glenii), pumpkinseed (Lepomis gibbosus) and rudd (Scardinius erythrophthalmus). We captured 192 specimens of the three fish species (see Table 1 for more details).

Standard length $(\mathrm{mm})$, total length $(\mathrm{mm})$ and wet mass $(\mathrm{g})$ of the captured fish were recorded after sampling. Individuals were dissected to remove their gut contents, then gender and weight of ovaries were determined in the laboratory and finally ovaries and empty guts were placed back in the fish. The whole carcasses were dried to constant weight at $60^{\circ} \mathrm{C}$ and dry mass was recorded. Afterwards, fish were coarsely homogenized with mortar and pestle, and were finally pulverized with

a Retsch MM 301 ball mill. We calculated the percent water content of fish with the following formula:

$$
\text { water content }=[\text { wet mass }(\mathrm{g})-\operatorname{dry} \text { mass }(\mathrm{g})] / \text { wet mass }(\mathrm{g}) \times 100 \text {. }
$$

Total carbon and nitrogen content of whole fishes were measured with a Vario EL CNS elemental analyzer. The total nitrogen content was converted to protein content according to Pangle and Sutton (2005):

$$
\text { protein content }=6.25 \times \text { total nitrogen content, }
$$


expressed as proportion of dry mass. Carbon content was also reported as proportion of dry mass. On the base of carbon and nitrogen contents, we determined the molar carbon:nitrogen ratios in the whole bodies. The total lipid content of fish bodies was extracted with a 2:1 mixture of chloroform-methanol at $20^{\circ} \mathrm{C}$ (Folch et al., 1957; Brown and Murphy, 2004). After centrifuging the suspension, the solvent was evaporated and finally the residual lipid content was measured gravimetrically. Lipid contents were also reported as the proportion of dry mass. Fulton's condition factor was calculated as:

$$
\text { K-factor }=\text { wet mass }(\mathrm{g}) / \text { standard length }(\mathrm{mm})^{3} \times 100 \text {. }
$$

Gonadal development was expressed by calculating gonado-somatic index, as:

$$
\text { gonado-somatic index }=\text { wet mass }(\mathrm{g}) / \text { wet mass of gonad }(\mathrm{g}) \times 100 \text {. }
$$

The relationship between the K-factor (response variable) and body composition (i.e., water content, lipid content, protein content, carbon content and carbon:nitrogen molar ratio), body size (total length) and gonadal development (gonado-somatic index) was tested by analysis of covariance (ANCOVA) with gender and season as factors (i.e., categorical variables) in the models. Additional ANCOVA models were run to test the relatedness of the lipid content (response variable) with the other descriptor variables, and gender and season were added again to the models as factors. To avoid collinearity, the effects of descriptor variables were tested individually in separate models. However, the interaction of gender and season was not included in the models due to limited sample sizes. Beta coefficients (i.e., the standardized regression slopes) were determined for each descriptor variable to compare the relative strength and direction of their relationships with K-factor and lipid content. Beta coefficients allowed the direct comparison of effects of different terms in linear models (Quinn and Keough, 2002). All statistical analyses were 
performed in the $\mathrm{R}$ environment ( $\mathrm{R}$ Core Team 2013) and evaluated at $\mathrm{P}<0.05$ significance level.

\section{Results}

In Table 1, we present means and standard deviations of the examined variables by species, seasons and genders. Lipid contents of the three species differed substantially; they ranged from $8.3 \%$ to $27.3 \%$ in rudd, from $9.3 \%$ to $19.4 \%$ in pumpkinseed and from $5.2 \%$ to $17.7 \%$ in Amur sleepers (Table 1).

ANCOVA models revealed that the water content had the most consistent effect on the K-factor, showing significant negative relationships in all fish species (Table 2). Significant positive relationship between the lipid content and the K-factor was found only in rudd. Furthermore, K-factor was positively related with the gonadosomatic index in Amur sleeper and pumpkinseed, with carbon: nitrogen molar ratio in Amur sleeper and rudd, with carbon content in Amur sleeper and with total length in pumpkinseed. The effect of season was significant in each model, whereas gender only proved to influence the relationship between the K-factor and gonado-somatic index in pumpkinseed.

ANCOVA models also indicated strong positive relationships between lipid content and carbon content, and carbon:nitrogen molar ratio in pumpkinseed and rudd (Table 3). In the Amur sleeper, lipid content decreased at higher carbon:nitrogen ratios and increased with total length. Water content was negatively related to lipid content in rudd. The effects of the categorical factors were roughly similar as found in the case of the K-factor: gender had negligible effect on body composition (it was significant only in one model), while season proved to be influential in the majority of the models. 


\section{Discussion}

Preceding studies reported inconsistent results on the predictive power of K-factor about specific body composition traits, especially in case of the lipid content in fishes. In this study, we explored this ecologically and physiologically important issue by evaluating the relationship between the $\mathrm{K}$-factor, body composition traits and other factors (such as size, gonadal development, gender of fish, and seasonality), which have been reported to influence this index (Simpson et al., 1992; McPherson et al., 2011). In line with some previous studies, we observed contradictory relationships regarding K-factor and lipid content, and found considerable interspecific differences. We presume that these findings can be partially explained by the various ranges of lipid contents in different fish species. Since changes of the K-factor reflects alterations of total body mass relative to the cube of fish length, the applicability of this index to indicate conditional changes is strongly dependent on to what extent the energy reserves vary and alter total body mass. The responses to the environmental effects were more intense in species with higher lipid contents, while stressors had less impact on the body composition of fish species with a narrower range of lipid content. We presume that a remarkable depletion in lipid content can lead to a substantial mass decrease which affects the length-weight relationships. Since generally lower lipid content does not allow such a high fluctuation, it probably has less effect on the length-weight relationships. On the other hand, although lipid reserves often constitute the primary energy resource in the body, carbohydrates (e.g., glycogen) also can be essential in storing energy (Chellappa et al., 1995). Because carbohydrate stores respond more rapidly to starvation than lipids (Love, 1970), we can deduce that higher proportion of 
carbohydrate stores can keep the lipid content at a relatively constant value. Thus, increased utilization of carbohydrates or any other non-lipid energy storing agents could reduce the strength of the relationship between lipid content and length-weight based condition indices.

Since lipids consist mostly of carbon, an increment in the lipid storages implies higher total carbon content and higher carbon:nitrogen molar ratios in body (Fagan et al., 2011). On the basis of that, we expected that the lipid content will show strong positive correlation with carbon content and carbon:nitrogen ratio; however the Amur sleeper exhibited the inverse of the expected relationship. This contradictory finding was presumably the consequence of the narrow lipid range and the highly variable protein content of that species. In that case, the carbon:nitrogen ratios may reflect the alternations of protein contents (rich in $\mathrm{N}$ ) rather than changes in lipid contents. However, changes in the protein content might not affect body mass appreciably, and we observed weak relationship between protein content and Kfactor similarly to the findings of Rønshold (1995).

The observed consistent negative linear association between $\mathrm{K}$-factor and the water content correspond with the finding of some previous studies. For instance, Brown and Murphy (1991) demonstrated that the relative mass and water content of fish were inversely related, and a similar type of relationship was reported between K-factor and water content by Pangle and Sutton (2005) as well. These results suggest that the morphometric indices can be reliable predictors of water content in fish. Since the water content and energy (e.g., lipid) content are negatively related (Lambert and Dutil, 1997), the K-factor can provide information indirectly about the energy reserves and the health of fish. In other words, higher water content in fish is usually coupled with lower K-factor values, which implies lower capability of fish to 
cope with environmental stressors, such as starvation. Several preceding studies pointed out that the water content of fish can serve as an alternative indicator of proximate composition, especially of lipid content (e.g., Love, 1970; Pangle and Sutton, 2005). However, our results seem to demonstrate that the negative coupling between lipid and water content does not apply universally to fish, although, its existence can be proven in some cases.

The observed interspecific differences in the effect of gonadal development on Kfactor presumably arise from the completely different reproductive strategies of these species. The gonadal development and spawning of rudd is synchronized within the population, while the Amur sleeper and the pumpkinseed are nest-guarding species and spawn in several portions during much longer reproduction periods. Consequently, the gonadal development of the latter two species can be highly variable among individuals of the same population. Our spring sampling has presumably missed the peak period of gonadal development of rudd, meanwhile Amur sleepers and pumpkinseeds have shown considerable differences in their gonadal development, thus the effect of that on K-factor was proven to be more significant in the latter two species.

In summary, our results demonstrated that the strength and direction of the relationship between K-factor and proximate body composition can be highly variable among fish species, and that the relationship can be influenced by the time of sampling but is independent of gender. We recognize that the present study has limitations and the results have to be treated with some caution due to the relatively low sample size in some treatments. Nevertheless, we believe that our findings can draw the attention to the importance of species-specific approaches when using the K-factor as a proxy of body component variables, and highlight that morphometric- 
based condition indices may serve as differently efficient predictors of energy reserves in different fish species.

\section{Acknowledgements}

We would like to thank the helpful contribution of András Specziár, Tímea Boros, Sára Kati, Zoltán Vitál, Zoltán Poller and Anikó Vászolyi to this project. This research was supported by the European Union and the State of Hungary, cofinanced by the European Social Fund in the framework of TÁMOP-4.2.4.A/ 2-11/12012-0001 'National Excellence Program'. The infrastructure of the research was supported by the EU and co-financed by the European Social Fund under the project ENVIKUT (TÁMOP-4.2.2.A-11/1/KONV-2012-0043).

\section{References}

Bolger, T.; Connolly, P.L., 1989: The selection of suitable indices for the measurement and analysis of fish condition. J. Fish Biol. 34, 171-182.

Boros, G.; Jyväsjärvi, J.; Takács, P.; Mozsár, A.; Tátrai, I.; Søndergaard, M.; Jones, R.I., 2012: Between-lake variation is elemental composition of roach (Rutilus rutilus L.). Aquat. Ecol. 46, 385-394.

Brown, M.L.; Murphy, B.R., 1991: Relationship of relative weight $\left(\mathrm{W}_{\mathrm{r}}\right)$ to proximate composition of juvenile striped bass and hybrid striped bass. T. Am. Fish. Soc. 120, $509-518$.

Brown, M.L.; Murphy, B.R., 2004: Seasonal dynamics of direct and indirect condition indices in relation to energy allocation in largemouth bass Micropterus salmoides (Lacépede). Ecol. Freshw. Fish 13, 23-36. 
Chellappa, S.; Huntingford, F.A.; Strang, R.H.C.; Thomson, R.Y., 1995: Condition factor and hepatosomatic index as estimates of energy status in male three-spined stickleback. J. Fish Biol. 47, 775-787.

Davidson, D.; Marshall, C.T., 2010: Are morphometric indices accurate indicators of stored energy in herring Clupea harengus? J. Fish Biol. 76, 913-929.

Fagan, K.-A.; Koops, M.A.; Arts, M.T.; Power, M., 2011: Assessing the utility of $\mathrm{C}: \mathrm{N}$ ratios for predicting lipid content in fishes. Can. J. Fish. Aquat. Sci. 68, 374385.

Fechhelm, R.G.; Griffiths, W.B.; Wilson, W.J.; Gallaway, B.J.; Bryan, J.D., 1995: Intra- and interseasonal changes in the relative condition and proximate body composition of broad whitefish from the Prudhoe Bay region of Alaska. T. Am. Fish. Soc. 124, 508-519.

Folch, J.; Lees, M.; Sloane-Stanley, G.H., 1957: A simple method for the isolation and purification of total lipids from animal tissues. J. Biol. Chem. 226, 497-509. Herbinger, C.M.; Friars, G.W., 1991: Correlation between condition factor and total lipid content in Atlantic salmon, Salmo salar., L., parr. Aquacult. Fish. Manage. 22, 527-529.

Hurst, T.P.; Conover, D.O., 2003: Seasonal and interannual variation in the allometry of energy allocation in juvenile striped bass. Ecology 84, 3360-3369.

Jonas, J.L.; Kraft, C.E.; Margenau, T.L., 1996: Assessment of seasonal changes in energy density and condition in age- 0 and age- 1 muskellunge. T. Am. Fish. Soc. 125, 203-210.

Kardi, S.; Metcalfe, N.B.; Huntingford, F.A.; Thorpe, J.E., 1995: What controls the onset of anorexia in maturing adult female Atlantic salmon? Funct. Ecol. 9, 790-797. 
Kaufman, S.D.; Johnson, T.A.; Leggett, W.C.; Moles, M.D.; Casselman, J.M.; Schulte-Hostedde, A.I., 2007: Relationship between body condition indices and proximate composition in adult walleyes. T. Am. Fish. Soc. 136, 1566-1576.

Lambert, Y.; Dutil, J.-D., 1997: Can simple condition indices be used to monitor and quantify seasonal changes in the energy reserves of Atlantic cod (Gadus morhua)? Can. J. Fish. Aquat. Sci. 54, 104-112.

Love, R.M., 1970: The chemical biology of fishes. Academic Press, New York, pp 547.

McPherson, L.R.; Slotte, A.; Kvamme, C.; Meier, S.; Marshall, T., 2011: Inconsistencies in measurement of fish condition: a comparison of four indices of fat reserves for Atlantic herring (Clupea harengus). ICES J. Mar. Sci. 68, 52-60.

Nash, R. D. M.; Valencia, A. H.; Geffen, A. J., 2006: The origin of Fulton's condition factor-setting the record straight. Fisheries 31, 236-238.

Neff, B.D.; Cargnelli, L.M., 2004: Relationship between condition factors, parasite load and paternity in bluegill sunfish, Lepomis macrochirus. Environ. Biol. Fish. 71, 297-304.

Pangle, K.L.; Sutton, T.M., 2005: Temporal changes in the relationship between condition indices and proximate composition of juvenile Coregonus artedi. J. Fish Biol. 66, 1060-1072.

Quinn, G.P.; Keough, M.J., 2002: Experimental Design and Data Analysis for Biologists. Cambridge University Press, pp 537.

Rønshold, B., 1995: Effect of size/age and feed composition on body composition and phosphorus content of rainbow trout, Oncorhynchus mykiss. Water Sci. Technol. 31, 175-183. 
Simpson, A.L.; Metcalfe, N.B.; Thorpe, J.E., 1992: A simple non-destructive biometric method for estimating fat levels in Atlantic salmon, Salmo salar L., parr. Aquacult. Fish. Manage. 23, 23-29.

Sutton, S.G.; Bult, T.P.; Haedrich, R.L., 2000: Relationship among fat weight, body weight, water weight and condition factors in wild Atlantic salmon parr. T. Am. Fish. Soc. 129, 527-538. 
Table 1 Descriptive statistics (mean and standard deviation) of the studied specimens by species, season and gender. Abbreviations: SP

- spring, SU - summer, AU - autumn; TL - total length, GSI - gonado-somatic index, WC - water content, LC - lipid content, PC protein content, $\mathrm{CC}-$ carbon content, $\mathrm{C}: \mathrm{N}$ - carbon:nitrogen molar ratio, $\mathrm{K}$ - Fulton's condition factor.

\begin{tabular}{|c|c|c|c|c|c|c|c|c|c|c|c|c|c|c|c|c|c|c|c|}
\hline & & & \multirow[t]{2}{*}{$\mathrm{n}$} & \multicolumn{2}{|c|}{$\mathrm{TL}$} & \multicolumn{2}{|c|}{ GSI } & \multicolumn{2}{|c|}{ WC } & \multicolumn{2}{|c|}{$\mathrm{LC}$} & \multicolumn{2}{|c|}{$\mathrm{PC}$} & \multicolumn{2}{|c|}{$\mathrm{CC}$} & \multicolumn{2}{|c|}{ C:N } & \multicolumn{2}{|c|}{ K } \\
\hline & & & & mean & SD & mean & SD & mean & SD & mean & SD & mean & SD & mean & $\mathrm{SD}$ & mean & SD & mean & SD \\
\hline \multirow{6}{*}{$\begin{array}{l}\overline{\bar{D}} \\
\bar{d} \\
\frac{\mathbb{d}}{\tilde{n}} \\
\dot{\Xi} \\
\dot{Z}\end{array}$} & & male & 11 & 6.40 & 1.14 & 0.85 & 0.43 & 79.51 & 0.56 & 11.74 & 2.01 & 64.57 & 0.82 & 40.83 & 0.66 & 4.61 & 0.10 & 2.42 & 0.24 \\
\hline & & female & 11 & 5.89 & 1.17 & 12.69 & 3.73 & 78.59 & 0.68 & 11.89 & 2.41 & 65.45 & 1.84 & 42.20 & 0.79 & 4.70 & 0.15 & 2.58 & 0.23 \\
\hline & & male & 10 & 7.30 & 0.59 & 0.59 & 0.39 & 78.97 & 1.42 & 10.98 & 1.28 & 68.16 & 1.36 & 40.09 & 1.68 & 4.29 & 0.15 & 2.08 & 0.14 \\
\hline & & female & 12 & 6.94 & 0.91 & 6.06 & 4.54 & 78.77 & 0.94 & 11.94 & 1.53 & 69.18 & 1.40 & 39.85 & 0.71 & 4.20 & 0.11 & 2.12 & 0.17 \\
\hline & \multirow{2}{*}{\multicolumn{2}{|c|}{ AU $\begin{array}{c}\text { male } \\
\text { female }\end{array}$}} & 15 & 7.20 & 1.56 & 0.33 & 0.21 & 78.78 & 0.60 & 10.50 & 2.59 & 62.83 & 2.41 & 38.39 & 1.39 & 4.46 & 0.20 & 2.25 & 0.13 \\
\hline & & & 7 & 6.23 & 1.46 & 2.65 & 0.53 & 78.85 & 0.41 & 8.23 & 1.63 & 61.56 & 2.60 & 38.55 & 0.82 & 4.57 & 0.21 & 2.28 & 0.16 \\
\hline \multirow{6}{*}{ 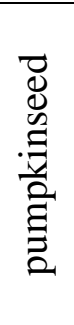 } & & male & 15 & 8.38 & 1.66 & 0.39 & 0.47 & 76.67 & 0.79 & 14.41 & 1.85 & 67.25 & 0.78 & 40.02 & 0.58 & 4.34 & 0.07 & 3.22 & 0.37 \\
\hline & & female & 8 & 7.39 & 1.76 & 1.38 & 0.58 & 76.48 & 0.72 & 14.26 & 2.49 & 11 & 1.63 & 40.05 & 0.73 & 4.40 & 0.10 & 25 & 0.34 \\
\hline & & male & 20 & 8.29 & 1.74 & 3.20 & 2.04 & 77.48 & 0.74 & 13.69 & 1.95 & 67.11 & 2.08 & 38.25 & 1.60 & 4.16 & 0.16 & 3.06 & 0.23 \\
\hline & & female & 4 & 8.20 & 0.22 & 8.57 & 3.75 & 75.81 & 1.08 & 15.13 & 2.39 & 67.11 & 1.01 & 41.04 & 1.50 & 4.46 & 0.11 & 2.97 & 0.25 \\
\hline & & male & 12 & 9.08 & 1.17 & 0.24 & 0.09 & 75.57 & 3.24 & 14.49 & 3.12 & 65.52 & 1.11 & 38.82 & 0.51 & 4.32 & 0.09 & 3.47 & 0.17 \\
\hline & & female & 8 & 7.44 & 1.17 & 1.19 & 0.25 & 75.22 & 2.65 & 17.19 & 1.85 & 65.64 & 1.12 & 40.76 & 1.19 & 4.53 & 0.14 & 3.22 & 0.39 \\
\hline \multirow{6}{*}{$\frac{\bar{\theta}}{2}$} & & male & 12 & 7.35 & 0.73 & 1.97 & 1.01 & 77.04 & 0.99 & 13.72 & 3.11 & 66.01 & 0.78 & 37.65 & 1.24 & 4.16 & 0.14 & 1.68 & 0.10 \\
\hline & & female & 9 & 7.64 & 0.86 & 3.38 & 1.28 & 77.35 & 0.83 & 13.54 & 3.30 & 65.67 & 1.75 & 37.05 & 1.16 & 4.11 & 0.08 & 1.70 & 0.07 \\
\hline & \multirow{2}{*}{ SU } & male & 10 & 8.78 & 0.45 & 0.08 & 0.17 & 73.69 & 1.64 & 21.83 & 3.32 & 61.39 & 2.12 & 41.34 & 1.16 & 4.92 & 0.29 & 1.84 & 0.08 \\
\hline & & female & 6 & 8.57 & 0.54 & 1.59 & 0.29 & 73.84 & 0.65 & 20.15 & 2.57 & 61.77 & 0.59 & 40.64 & 1.07 & 4.80 & 0.15 & 1.81 & 0.10 \\
\hline & \multirow{2}{*}{$\mathrm{AU}$} & male & 7 & 10.07 & 1.34 & 1.44 & 1.22 & 74.35 & 0.81 & 12.11 & 3.71 & 64.93 & 1.66 & 38.15 & 1.62 & 4.28 & 0.16 & 1.91 & 0.08 \\
\hline & & female & 15 & 9.92 & 1.13 & 4.70 & 0.92 & 74.56 & 0.75 & 13.64 & 2.45 & 64.85 & 1.29 & 38.25 & 1.37 & 4.30 & 0.15 & 1.87 & 0.08 \\
\hline
\end{tabular}


Table 2 Results of the ANCOVA models testing effects of the total length (TL), gonado-somatic index (GSI), water content (WC), lipid content (LC), protein content (PC), carbon content $(\mathrm{CC})$, carbon:nitrogen molar ratio $(\mathrm{C}: \mathrm{N})$, as well as two categorical variables, gender and season, on $\mathrm{K}$-factor (response variable). Adj. $\mathrm{R}^{2}-$ adjusted determination coefficient of the model.

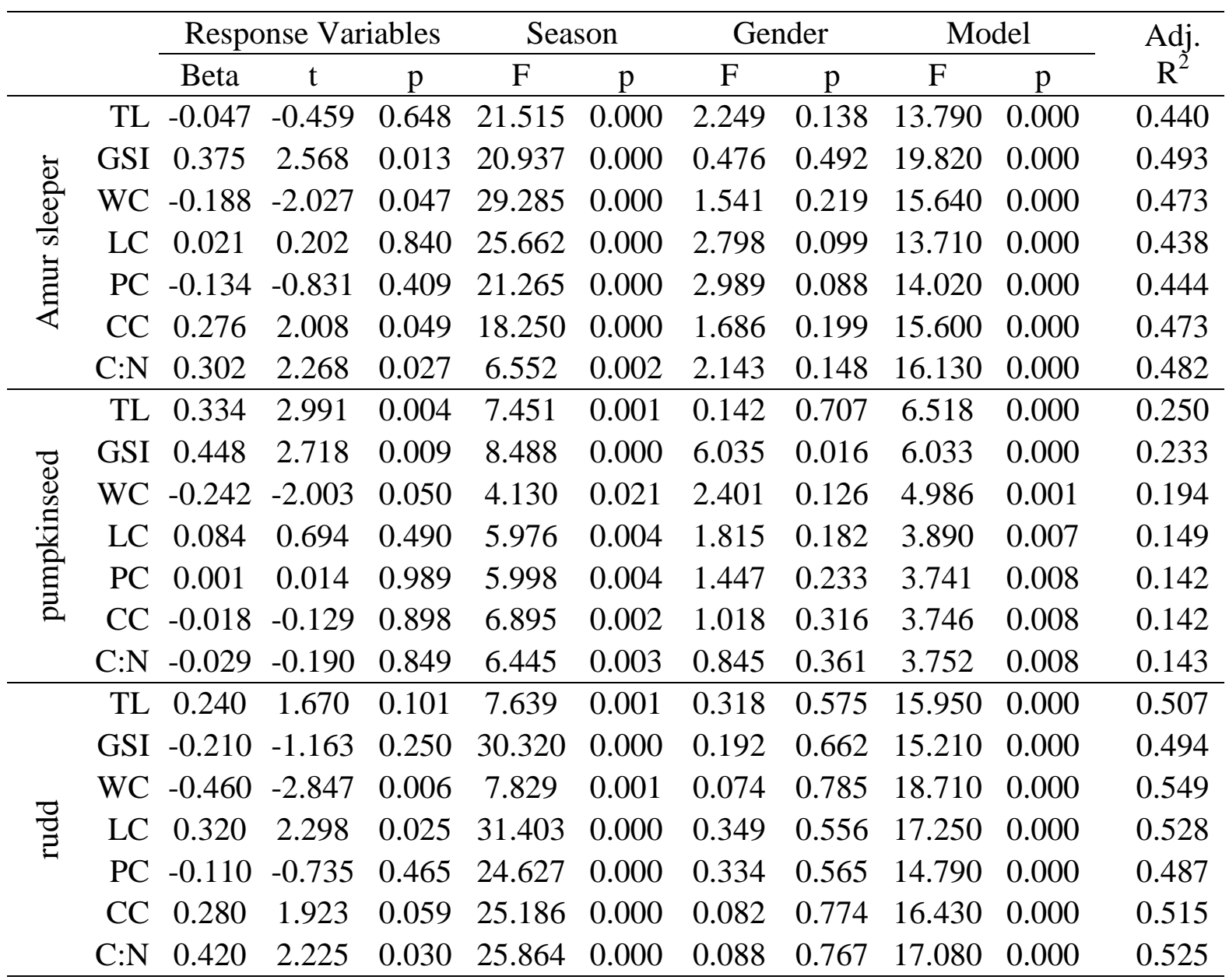


Table 3 Results of the ANCOVA models testing effects of the total length (TL), gonado-somatic index (GSI), water content (WC), protein content (PC), carbon content (CC), carbon:nitrogen molar ratio $(\mathrm{C}: \mathrm{N})$, as well as two categorical variables, gender and season, on lipid content of fish (response variable). Adj. $\mathrm{R}^{2}$ - adjusted determination coefficient of the model.

\begin{tabular}{|c|c|c|c|c|c|c|c|c|c|c|c|}
\hline & \multicolumn{3}{|c|}{ Response variables } & \multicolumn{2}{|c|}{ Season } & \multicolumn{2}{|c|}{ Gender } & \multicolumn{2}{|c|}{ Model } & \multirow{2}{*}{$\begin{array}{l}\text { Adj. } \\
\mathrm{R}^{2}\end{array}$} \\
\hline & & Beta & $\mathrm{t}$ & $\mathrm{p}$ & $\mathrm{F}$ & $\mathrm{p}$ & $\mathrm{F}$ & $\mathrm{p}$ & $\mathrm{F}$ & $\mathrm{p}$ & \\
\hline \multirow{6}{*}{$\begin{array}{l}\overline{\bar{d}} \\
\frac{\bar{d}}{\tilde{D}} \\
\bar{\Xi} \\
\bar{\Xi}\end{array}$} & TL & 67 & & & 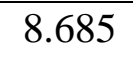 & & 28 & & 840 & & 0.229 \\
\hline & GSI & 0.225 & 1.176 & 0.244 & 4.452 & 0.015 & 1.571 & 0.214 & 3.400 & & .128 \\
\hline & WC & 0.114 & 0. & 0.3 & 5.494 & 6 & 25 & & 3.260 & & 122 \\
\hline & PC & 0.334 & & & 956 & & 99 & & 829 & & 148 \\
\hline & $\mathrm{CC}$ & -0 . & & & 15 & & & & 87 & & 118 \\
\hline & $\mathrm{C}: \mathrm{N}$ & -0.343 & -2.031 & 0.0 & 7.452 & 0. & 0.126 & & 4.220 & & .165 \\
\hline \multirow{6}{*}{ 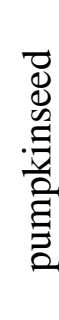 } & TL & 0.039 & 0.321 & 0.74 & 2.935 & & 4.061 & & 2.487 & & .082 \\
\hline & GSI & 0.223 & 1.255 & 0.2 & 5.087 & 0.008 & 307 & & 13 & & 103 \\
\hline & WC & -0.011 & -0. & & 2.139 & & & & 2.459 & & .081 \\
\hline & $\mathrm{PC}$ & 0.144 & 1.116 & 0.2 & 3.380 & 0. & 4.481 & & 2.818 & & 0.099 \\
\hline & $\mathrm{CC}$ & 0.399 & 2.951 & 0.004 & 2.703 & 0. & 0.266 & 0. & 4.890 & 0. & .194 \\
\hline & $\mathrm{C}: \mathrm{N}$ & 0.342 & & & 0.995 & & 0.341 & & 3.851 & & .147 \\
\hline \multirow{6}{*}{$\frac{\bar{Z}}{\Xi}$} & & 0.262 & & 0.1 & 41.7 & & 0.000 & & 20.970 & & 0.579 \\
\hline & GSI & 0.167 & 1.0 & 0.316 & 26.755 & 0.0 & 0.520 & 0. & 19.330 & 0. & .558 \\
\hline & WC & -0.597 & -4.302 & 0.000 & 33.697 & 0.000 & 0.250 & 0.618 & 29.760 & & 0.667 \\
\hline & $\mathrm{PC}$ & -0.208 & & & 11.766 & & 0.000 & & 20.060 & & 0.567 \\
\hline & $\mathrm{CC}$ & 0.557 & & 0.000 & 8.230 & 0.0 & 0.523 & 0.4 & 32.380 & & .684 \\
\hline & $C: N$ & 0.802 & 5.530 & 0.000 & 4.708 & 0.013 & 0.513 & 0.476 & 36.960 & 0.000 & 0.712 \\
\hline
\end{tabular}

